\title{
Impact of Morocco-ECOWAS Economic Relations on Economic Growth in Morocco: An Analysis Using the ARDL Model
}

\author{
Hidaya EL Khattabi ${ }^{1} \&$ Mohamed Karim ${ }^{1}$ \\ ${ }^{1}$ EREMEFP, University of Mohammed V, Rabat, Morocco \\ Correspondence: Hidaya EL Khattabi, University of Mohammed V, Rabat, Morocco. Tel: 212-661-683-260. \\ E-mail: xmedkarimx@gmail.com
}

Received: March 10, 2018

Accepted: April 3, 2018

Online Published: April 10, 2018

doi:10.5539/ijef.v10n5p105

URL: https://doi.org/10.5539/ijef.v10n5p105

\begin{abstract}
Over the last decade, Morocco has undertaken numerous reforms in order to successfully integrate itself into the global economy in general, and Africa in particular, with the aim of diversifying and strengthening its competitive export potential.

In fact, the analysis of trade relations between Morocco and ECOWAS reveals an increasing volume of trade, reflecting a continuous dynamization of their commercial relations. A similar trend is observed in foreign direct investment, which has been growing steadily over the last few years, reflecting Morocco's desire to become a major player in the development of the African continent.

The analysis of Morocco's trade opening and foreign direct investment (FDI) in ECOWAS on Morocco's economic growth, using ARDL (Autorégressive distribution Lag) modelling, shows that Moroccan foreign direct investment to ECOWAS has a significant impact on its GDP per capita in the short and long term. With regard to bilateral trade between the two partners, no long-term equilibrium relationship could be established due to the still low weight of trade volumes.
\end{abstract}

Keywords: ECOWAS, Morocco, trade and investment exchanges, Cointegration, ARDL

\section{Introduction}

A few months after joining the African Union after thirty-three years of absence, Morocco has now taken another step towards ECOWAS (Note 1), one of the eight regional economic communities (RECs).The Economic Community of West African States (ECOWAS) was created by the Treaty of Lagos (Nigeria), in 1975. It was created to promote economic trade, national cooperation, and monetary union, for growth and development throughout West Africa.

Morocco's willingness to integrate this area is a strategic decision with a strong political and economic dimension, as it intervenes to consolidate the strong, deep and multidimensional ties of cooperation between Morocco and the member countries, within the framework of the royal vision advocating regional integration as a vector of economic acceleration in Africa.

At the political level, Morocco had already participated in several ECOWAS meetings as an observer and had provided assistance in the field of peace and stability. He has participated in the peacekeeping operation in Ivory Coast, crisis resolution in Guinea and the fight against Ebola.

On the economic level, Morocco has initiated structural projects with ECOWAS countries, such as the Morocco-Nigeria gas pipeline and the promotion of a north-western African area of strategic dialogue and consultation for concrete and multifaceted cooperation between the countries of the north-western African region.

Moreover, Morocco is today the major African partner and investor in ECOWAS. Indeed, several leading Moroccan companies, operating notably in the banking, insurance, telecommunications and construction sectors, have extended their activities to several African countries and generate a large part of their turnover and profits from their investments.

With its future membership of this community, Morocco hopes to contribute even more directly to ECOWAS activities, particularly in the areas of stability, economic progress and sustainable human development. As a full member, Morocco will also be able to have more direct access to a market of nearly 350 million people, i. e. almost 
$40 \%$ of the population of sub-Saharan Africa. Morocco will also benefit from export facilities and will be able to further consolidate its growth on the continent. It will also considerably strengthen the organization, bringing in its $\$ 100$ billion GDP, to be the 17th largest economic power acapita of Turkey, Switzerland and Saudi Arabia.

Integration will also facilitate Moroccan investment in this region. African countries offer investment opportunities in various sectors, including those where Moroccan companies have acquired expertise and experience. The community will be able to benefit from the advances recorded by Morocco as it will bring its industrial expertise in several economic sectors, such as the automotive industry, renewable energies, aeronautics, infrastructure... In addition to these direct advantages, ECOWAS will benefit from Morocco's privileged relations with its international partners, notably the European Union and its strong links with the countries of the Gulf Cooperation Council.

The present study, through an ARDL model, analyses the contribution of trade and investment relations between Morocco and ECOWAS to the Moroccan economy, focusing on the 2008-2016 period.

\section{Status of Trade Exchanges between Morocco and ECOWAS}

Over the 2000-2016 period, Morocco's trade with ECOWAS increased by $12.3 \%$ on average annually to reach nearly MAD9.5 billion in 2016, compared to MAD1.5 billion in 2000, or six times more than in sixteen years.

Moreover, Morocco's exports to ECOWAS have almost tripled since 2008, rising from MAD2.8 billion to MAD8.5 billion in 2016. Moroccan exports to sub-Saharan Africa were 37.3\% of Moroccan exports to ECOWAS in 2016, which makes this region the main destination for Moroccan regional exports.

On the other hand, there has been a positive but limited increase in the amount of imports from this region. They stood at MAD1 billion in 2016 compared to MAD2.7 billion in 2011, their highest level over the period, and MAD0.6 billion in 2000. The trade balance, largely surplus in favour of Morocco, has strengthened significantly in recent years to reach MAD 7.2 billion in 2016.

It is therefore logical that Morocco should embark on this extremely promising market of nearly 350 million habitants, considered more a zone of consumption and import than production and export. Integrating a free trade area will be a formidable tool for Morocco, which will undoubtedly be able to expand its market and develop exchanges with ECOWAS countries (which absorb between $50 \%$ and $60 \%$ of its exports), noting that this will be likely to promote job creation and poverty reduction.

Morocco's main customers in the ECOWAS zone are Senegal (23\% on average of Morocco's total exports to the region over the 2008-2016 period), followed by Ivory Coast (15\%), Nigeria (13\%), Ghana (11\%) and Guinea (9\%). In 2016, these countries received almost 70\% of exports to ECOWAS. For imports, Nigeria is Morocco's main supplier, accounting for more than half of Morocco's imports from the zone (57.3\%), followed by Ivory Coast, Guinea and Ghana with $9.4 \%, 9.3 \%$ and $6.6 \%$ respectively of total imports from the zone for the same period.

Food products rank first among the products exported by Morocco to ECOWAS, acapita of semi-finished products and finished consumer products. Moroccan imports from ECOWAS concern food and some agricultural products.

The steady increase in trade between Morocco and its ECOWAS partners since 2000 suggests that there is potential for trade development, as evidenced by Morocco's market share in ECOWAS, which has improved from $0.3 \%$ in 2000 to $0.5 \%$ in 2008 and $0,8 \%$ in 2015. Indeed, Moroccois the 25th supplier of the ECOWAS zone, 21th supplier of the zone (excluding ECOWAS countries), the 6thAfrican country supplier of this zone (behind Nigeria, South Africa, IvoryCoast, Senegal and Ghana), and the 2ndAfrican supplier of the zone (excluding ECOWAS countries) for the year 2016. As a result, Morocco is slightly better positioned than Sweden, Tunisia, Egypt and Saudi Arabia, but far behind countries such as Japan, Brazil, Spain and Germany and especially far from certain emerging countries such as China and India.

In addition, the calculation of the diversification (Note 2) index over the period 2000-2014 shows a strong diversification of Moroccan exports to ECOWAS countries, alternating between 0.5 and 0.8 during the period 2000-2014. Similarly, if we look at export diversification from the point of view of the number of exported products, Morocco now exports nearly 153 products to it, compared with only 61 products in 2000.

In addition, the export intensity index (Note 3) between Morocco and ECOWAS increased from 3.4 to 4.5 between 2000-2007 and 2008-2015. This bodes well for Morocco's preference for the West African market.

For its part, the complementarity index (Note 4) of Morocco's exports with ECOWAS countries is relatively low, varying on average between 0.08 (with Guinea-Bissau) and 0.27 (with Senegal) during the period 2000-2013. 
Intra-regional trade in Africa is often characterized by the poor complementarity of national production.

In short, Morocco's potential for trade with ECOWAS does indeed exist and is being exploited relatively well. It must now be consolidated through appropriate mechanisms and targeting of the branches and sectors that Morocco can export to its partners, while maximizing its trade complementarity in order to better meet the demand for imports from these countries.

\section{Foreign Direct Investment from Morocco to ECOWAS}

Beyond trade, Morocco's financial relations with Africa are particularly marked by the significant weight of foreign direct investment (FDI) flows. These flows, mainly originating in Morocco, have accelerated in recent years towards this continent, particularly in West Africa. In this regard, it should be noted that ECOWAS has been attracting more and more FDI for several years. The latter reached 59 billion dollars in 2009 and they come from both developed and developing countries, notably African countries (South Africa, Morocco, Algeria...).

Among the African States that have received the most FDI from Morocco in recent years, ECOWAS countries ranked highest, with an average of $68.1 \%$ between 2008 and 2016, and a peak of $96 \%$ in 2008. For the year 2016 alone, investments in this zone reached more than 2 billion dirhams, representing more than half of Moroccan direct investments in sub-Saharan Africa. Morocco thus presents itself as a significant investor within ECOWAS.

Over the 2008-2016 period, four countries accounted for 89.4\% of Morocco's investments. Ivory Coast and Mali remain the main recipients of Moroccan investment in the region, with a share of $34.6 \%$ and $34.4 \%$ respectively, followed by Senegal (16.3\%) and Nigeria (4.2\%).

Moroccan direct investments in the region target sectors with high added value such as banks, telecommunications or real estate, and are mainly carried out by companies/banks such as Maroc Telecom, Attijariwafa Bank, BMCE, BCP and RAM...

Moroccan FDI towards ECOWAS should continue its upward trend in the coming years, given Morocco's desire to strengthen its relations with this region. Morocco's opening up to this market is an opportunity to direct its investments towards sectors where they can boost domestic investment, create jobs and stimulate productive capacities in order to foster Morocco's regional integration with the rest of Africa. Moreover, the participation of Moroccan expertise in supporting its investment projects would have a positive impact on know-how and technology in the host countries.

The rapprochement between Morocco's trade and FDI in the region, over the same period from 2008 to 2016, clearly distinguishes three groups of countries. ECOWAS countries that are important both in Morocco's trade and as recipients of its FDI are limited to two countries, Senegal and Nigeria. Important countries such as Mali and Ivory Coast, which are important destinations for Morocco's outward FDI, and only moderately present in its foreign trade with the region. On the other hand, some countries realize an important value of exchanges with Morocco but receive little or no FDI flows, such as Guinea, Ghana, Togo and Burkina Faso.

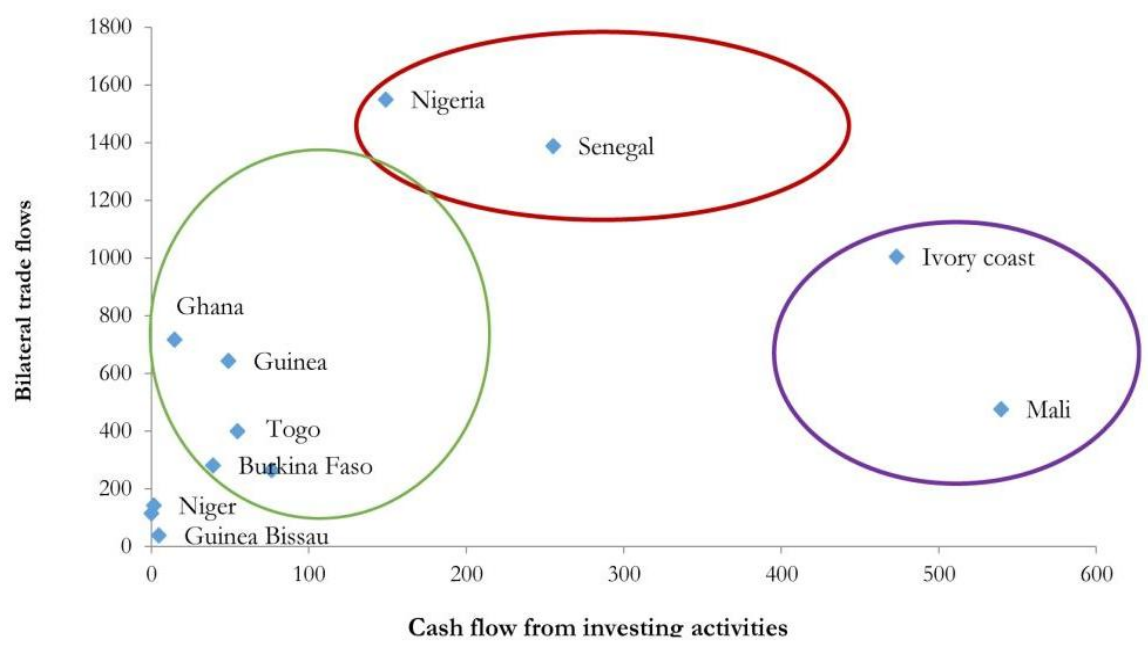

Figure 1. Reconciliation between FDI flows and trade flows for ECOWAS countries (average for the period 2008 and 2016, MAD million)

Source: Authors' production based on data from the Exchange Office. 


\section{Literature Review}

One of the topics of great interest in international economics is the influence of openness to foreign trade on economic growth. Trade liberalization is now seen as a source of convergence and a key element for development strategies. Indeed, a number of international organizations are encouraging countries to liberalize their trade. For some of them, such as the International Monetary Fund and the World Bank, the liberalization of trade policies is often a major condition for providing financial or economic assistance to developing countries.

In the current context of globalization, it is natural to question the links between openness to foreign trade and economic growth. Unambiguous evidence of a positive and significant impact of openness on growth will encourage governments wishing to improve their situation to adopt trade liberalization policies. In addition, the impressive economic success of East Asian countries reinforces the idea that such a development strategy is effective and desirable.

The theory of free trade appeared in the 18th century among classical economists who opposed mercantilism, the dominant doctrine of the time. Adam Smith, one of the leading classical writers, is at the origin of the theory of absolute advantage that open borders are conducive to development, job creation and poverty reduction. His theory is taken up by David Ricardo, who shows that everyone can benefit from international exchange. In the middle of the 20th century, the classical theses were renewed by Heckscher, Ohlin, then Samuelson, who developed what became the reference model of international trade. This justifies free trade and specialisation at the international level by the existence of differences in inputs. Proponents of free trade expect the following benefits from free trade:"optimal allocation of resources, increased global welfare, efficient division of labour..., peace among nations" (de Agostino, 2003, p. 126). But its effects on inequality, peace or development are uncertain, as Serge d'Agostino (2003, p. 126) put it:"the gains of free trade are rarely equal to what the theory suggests, and it is not uncommon for the results of trade liberalization to be negative".

According to Levine and Renelt's (1992) study, the causal relationship between openness and growth is through investment. If openness to international trade allows access to capital goods, it will lead to long-term growth. A country liberalizing its trade will attract foreign investment flows. However, this could lead to a drop in domestic investment due to stronger international competition, and the net effect remains ambiguous.

For Batra (1992) and Leamer (1995), liberalization of trade reduces tariffs, and therefore reduces the relative price of manufactured household goods. These goods become less attractive than foreign goods, and the domestic economy can suffer a loss.

Other studies, such as those by Grossman and Helpman (1991), Romer (1990) and Rivera-Batiz and Romer (1991), focus on the long-term implications of government intervention in trade. They see innovation as a source of growth and therefore encourage open policies. In their models, the gains of free trade come mainly from the scale effects transmitted through research and development. The innovation generated contributes to increasing the stock of knowledge and technology transfer.

Since theoretical studies have not succeeded in deciding whether or not trade openness contributes to economic growth, the various empirical studies on the subject have, on the other hand, produced similar results or the effect of openness is generally favourable to growth.

During the 1970s, most empirical work used cross-sectional regressions across a range of countries. The correlation coefficients were either between export growth and GDP, or between indices representing trade openness or policies and long-term growth. Most of these studies have established a positive relationship between openness and growth.

Subsequently, thanks to the fusion of the endogenous growth theory and the new theory of international trade, work was then concentrated on the pathways of influence of openness on growth: the formation of captains. Dollar (1992), Barro and Sala-I-Martin (1995), Sachs and Warner (1995), Edwards (1998) and Greenaway et al. (1998), using cross-sectional regressions, found that distortions due to state intervention in trade led to low growth rates.

Frankel and Romer (1999) use a method with instrumental variables including geographical characteristics, and confirm that international trade has a significant and significant impact on growth. Harrison (1996) comes to similar conclusions using a variety of openness indicators. Using different estimation methods (cross-sectional cross-section, fixed effects, five-year average, first differences), the results suggest a positive relationship between openness and growth.

In summary, the empirical work is able to demonstrate a positive impact of openness on growth, but its robustness is questioned. They run up against several econometric limits, including the relevance of the choice of 
the openness indicator.

Faced with the changes in the international environment, the creation of a free trade area appears to be a viable alternative; free trade is not an option, but rather a requirement. In this vein, in order to create an environment conducive to the development of its trade with third countries, Morocco has sealed its trade opening policy by negotiating a series of Free Trade Agreements (FTAs) with its main trading partners such as the European Union, Arab countries, the United States of America and Turkey.

In Africa, bilateral economic and commercial cooperation has always been an important lever for action in Morocco's strategy. Since the 1960s, Morocco has developed an important network of bilateral cooperation agreements with these countries, through the formulation of an appropriate regulatory framework. Today, this African vocation has taken on a new dimension as part of a long-term vision based on the virtues of South-South cooperation and the imperative of human development, in the establishment of fair and balanced economic relations. Economic relations between Morocco and African countries are governed by a legal framework of more than 500 cooperation agreements. They are distinguished by the involvement of the private sector in the various government initiatives aimed at the continent.

\section{Methodology}

\subsection{Data}

The variables used in this study are :

- GDP/capita: the level of GDP per capita;

- TRADE: the volume of trade or trade opening between Morocco and ECOWAS, expressed as the sum of exports and imports as a percentage of GDP;

- $\quad$ FDI: represents FDI flows out of Morocco to ECOWAS;

- INV stands for investment (gross fixed capital formation);

- SCHOL is a proxy for the stock of human capital through the gross primary school enrolment rate;

- FDI*TRADE: assesses whether trade and FDI are complementary or substitutable, in order to understand that FDI regimes depend on trade policies (AfDB, 2009).

The data come from the national accounts of the HCP (Hig commission for planning) and the Exchange Office. For reasons of heterogeneity of the time intervals at which the variables studied are available, it is important to choose a common interval which groups together all the selected variables, in this case between 2008 and 2016.

\subsection{The Model}

To study the effect of trade openness and FDI between Morocco and ECOWAS on Morocco's economic growth, the ARDL (Autoregressive Distribution Lag) model developed by Pesaran and Smith (1998) is used. The term"self regressive" means that the delayed dependent variable can determine the dependent variable present whereas the term"ditributed lag" refers to the delay of the independent variables.

First, unit root tests are performed for the variables using the ADF test to study the stationarity of the variables and their degree of integration. Then, the model is analyzed using the Autoregressive-Distributed Lag procedure because of the need to take stock of the long-term and short-term consequences of our analysis.

The ARDL Bound testing approach is preferred to other cointegration techniques for several reasons. First, it is more appropriate for estimating long-term relationships for small sample sizes. Second, this methodology can be applied if the variables used are of different integration level. According to Pesaran and Shin (1995), the ARDL approach provides robust and better estimates for small sample sizes and reliability of long-term coefficients than other cointegration techniques.

The empirical specification of the model is as follows:

$$
\begin{gathered}
\Delta \ln (G D P / \text { capita })=\alpha+\text { wtrend }+\sum_{i=1}^{p} \beta_{i} \Delta \ln \left(G D P / \text { capita }_{t-i}\right)+\sum_{i=1}^{p} \delta_{i} \Delta \ln \left(I N V_{t-i}\right)+ \\
\sum_{i=1}^{p} \pi_{i} \Delta \ln \left(\text { SCHOL }_{t-i}\right)+\sum_{i=1}^{p} \theta_{i} \Delta \ln \left(T R A D E_{t-i}\right)+\sum_{i=1}^{p} \lambda_{i} \Delta \ln \left(F D I_{t-i}\right)+\sum_{i=1}^{p} \varphi_{i} \Delta \ln (F D I * \\
\left.T R A D E_{t-i}\right)+\rho_{1} \ln \left(G D P / \text { capita }_{t-1}\right)+\rho_{2} \ln \left(I N V_{t-1}\right)+\rho_{3} \ln \left(\text { SCHOL }_{t-1}\right)+ \\
\rho_{4} \ln \left(T R A D E_{t-1}\right)+\rho_{5} \ln \left(F D I_{t-1}\right)+\rho_{6} \ln \left(F D I * T R A D E_{t-1}\right)+\gamma_{1 t}
\end{gathered}
$$

The ARDL approach tests the existence of a long-term relationship through the null hypothesis of no cointegration (H0: $\left.\rho_{1}=\rho_{2}=\rho_{3}=\rho_{4}=\rho_{5}=\rho_{6}=0\right)$. To do this, the calculated values of the Fisher statistics are compared with the critical values simulated by Pesaran et al. This test provides two critical values (upper bound and lower 
bound). If the calculated F statistic exceeds the upper limit, then the null hypothesis of no cointegration can be rejected, and thus there is a long-term relationship between the variables. While if the calculated $\mathrm{F}$ statistic is below the lower limit, the null hypothesis of no cointegration cannot be rejected, and the long-term relationship between the variables cannot be confirmed. However, the inference is inconclusive if the calculated statistic is between the two bounds.

In the second step, the order of delay in the ARDL model is determined using the Schwartz Information Criterion (SIC) and then the chosen model is estimated using the ordinary least squares method to obtain a long-term estimate. This long-term estimate, from the selected ARDL specification, gives an estimate of the coefficients of the cointegration relationship.

The other important element in the ARDL approach is the choice of the optimal number of offsets (delays) that can significantly affect the quality of the results. Generally, according to Pesaran and Shin (1999) a maximum number of delays is set first and then, the optimal choice will be based on the minimization of Akaike's information criteria (AIC). Given the small sample size (2008-2016), the maximum number of delays is set at one and the validity of the model is examined in the light of diagnostic tests.

\section{Results}

The exploratory analysis of the data shows that Morocco's GDP per capita increased throughout the 2008-2016 period, averaging MAD26216 with a minimum of MAD22.996 in 2008. The volume of trade between Morocco and ECOWAS remains low at $0.86 \%$ over the period, i. e. MAD 7166.2 million. Foreign direct investment with MAD 4427.2 million represents only about $0.54 \%$ of Moroccan GDP between 2008 and 2016. Moreover, Morocco has a relatively high investment rate of $32.8 \%$ of GDP with a maximum of 35\% in 2008.

Table 1. Descriptive statistics

\begin{tabular}{lccccccc}
\hline & GDP/capita & $\begin{array}{c}\text { TRADE as \% } \\
\text { of GDP }\end{array}$ & $\begin{array}{c}\text { FDI as \% } \\
\text { of GDP }\end{array}$ & $\begin{array}{c}\text { FDI (millions } \\
\text { of dirham) }\end{array}$ & $\begin{array}{c}\text { TRADE (millions of } \\
\text { dirham) }\end{array}$ & $\begin{array}{c}\text { SCHOL as \% of } \\
\text { GDP }\end{array}$ & $\begin{array}{c}\text { INV as \% } \\
\text { of GDP }\end{array}$ \\
\hline Mean & 26216 & 0,86 & 0,54 & 4427,2 & 7166,2 & 113,5 & 32,8 \\
Median & 26011 & 0,9 & 0,5 & 3959 & 7814,9 & 115 & 33,2 \\
Minimum & 22996 & 0,5 & 0,2 & 7362 & 3400 & 107,2 & 30,7 \\
Maximum & 29464 & 1,2 & 0,8 & 1710 & 9749,5 & 116,7 & 35 \\
Jarque-Bera & 0,54 & 0,65 & 0,35 & 0,51 & 1 & 0,14 & 0,21 \\
Probability & 0,76 & 0,71 & 0,83 & 0,77 & 0,6 & 0,92 & 0,9 \\
\hline
\end{tabular}

Source. Authors' calculations.

The application of unit root ADF tests on the studied series results in rejecting the stationarity hypothesis for all series except TRADE, which is stationary in level. The results also show that the other series are integrated in order 1 I (1). Therefore, no series is integrated in order two I (2) or more, which is essential for the application of ARDL.

Table 2. Stationarity test results (ADF)

\begin{tabular}{lccccc}
\hline & \multicolumn{2}{c}{ Level Variable Logarithm } & \multicolumn{2}{c}{ First Difference } & \multirow{2}{*}{ Integration order } \\
\cline { 2 - 5 } & t-statistic & Specification & t-statistic & Specification & \\
\cline { 1 - 4 } GDP/capita & $-6,4$ & Trend+Ct & $-7,5$ & Constant & I $(1)$ \\
INV & $-2,8$ & Constant & $-3,2$ & none & I $(1)$ \\
SCHOL & $-2,07$ & Trend+Ct & $-2,8$ & none & I $(1)$ \\
FDI & $-2,1$ & Trend+Ct & $-4,3$ & none & I $(1)$ \\
TRADE & $-2,4$ & none & $-3,5$ & none & I $(0)$ \\
FDI*TRADE & $-4,6$ & Trend+Ct & $-5,4$ & none & I $(1)$ \\
\hline
\end{tabular}

Source. Authors' calculations.

Three models are estimated as part of this analysis. For each, the level of GDP per capita is regressed on the control variables used in the traditional growth models of physical and human capital, which are captured here by investment (INV) and enrolment rates (SCHOL). In addition to these variables, the model (1) also includes the interaction between FDI and trade (IDE*TRADE), the model (2) analyses the effect of FDI while in the model (3) the effect of trade (TRADE) is captured. 
The existence of a long-term equilibrium relationship in the ARDL approach is analysed according to the Fisher test (Pesaran et al., 2001). The Fisher statistics calculated for Models 1 and 2 are higher than the upper bound value. Thus the model 1 including GDP per capita, education level (SCHOL), investment (INV) and interaction (IDE*TRADE) maintain a long-term equilibrium relationship. This same long-term relationship is found for model 2 variables. On the other hand, no long-term equilibrium relationship was found in Model 3.

Thus, and after having verified the selection criteria for the models, it is noted that the explanatory powers of models 1 and 2 are acceptable of $73 \%$ and $81 \%$. Residue diagnostic tests indicate that the models are well specified.

Table 3. Co-integration test

\begin{tabular}{lccc}
\hline Model & F-statistics & Critical values (Upper bound) & Nomber de K* \\
\hline Model 1 & 8,3 & 4,44 & 3 \\
Model 2 & 4,6 & 3,48 & 3 \\
Model 3 & 2,9 & 3,48 & 3 \\
\hline
\end{tabular}

* Number of regressors.

Source. Authors' calculations.

The results of the estimates of long-term relationships obtained, within the framework of the specification used, lead to the conclusion that investment and educational attainment have a positive effect on GDP per capita. These results are confirmed in the empirical literature on the determinants of economic growth. Moreover, the impact of education on growth appears to be more robust than that of investment. Indeed, according to theorists of endogenous growth, human capital remains a fundamental determinant of long-term economic growth.

Table 4. Estimations

\begin{tabular}{|c|c|c|c|}
\hline & Model (1) & Model (2) & Model (3) \\
\hline & $\operatorname{ARDL}(1,0,0,0)$ & $(1,0,1,0)$ & $(1,0,0,1)$ \\
\hline D(SCHOL) & 0,000963 & & 0,000907 \\
\hline D(INV) & $-0,026309$ & & \\
\hline $\mathbf{D}(\mathbf{F D I})$ & & 0,013378 & \\
\hline \multicolumn{4}{|l|}{ D(TRADE) } \\
\hline D(FDI*TRADE) & 0.012476 & & \\
\hline Constante & 7,386305 & 9,54007 & 0,564023 \\
\hline SCHOL(-1) & 0,025474 & 0,024101 & 0,003288 \\
\hline $\operatorname{INV}(-1)$ & 0,023574 & 0,185489 & 0,023571 \\
\hline FDI(-1) & & 0,035283 & \\
\hline TRADE(-1) & & & 0,014832 \\
\hline FDI*TRADE(-1) & 0,035323 & & \\
\hline GDP(-1) & $-1,387817$ & $-1,858246$ & $-0,783864$ \\
\hline Adjusted $\mathbf{R}^{2}$ & 0,73 & 0,81 & 0,37 \\
\hline Breusch Pagan Godfrey & 0,19 & 0,15 & 0,6 \\
\hline Ramsey reset test & 0,57 & 0,47 & 0,63 \\
\hline $\begin{array}{l}\text { Long-term equilibrium } \\
\text { coefficients }\end{array}$ & $\begin{array}{c}\text { LGDP_ST }=3.4821868+ \\
\text { 0.1323359*LSCHO_ST + } \\
\text { 0.01675915*LINV_ST } \\
+ \text { +0.0011148*LFDITRADE_ST } \\
\end{array}$ & $\begin{array}{c}\text { LGDP_ST }=6.4689531+ \\
0.0574520157416 * \text { LSCHO_ST + } \\
0.1102569 * \text { LINV_ST } \\
+0.0016109 * \text { LFDI_ST }\end{array}$ & $\begin{array}{l}\text { No long-term } \\
\text { relationship exists }\end{array}$ \\
\hline
\end{tabular}

Source. Authors' calculations.

Moreover, the interaction between trade and FDI has a positive effect on economic growth (the explanatory power of the model is $73 \%$ acceptable). Thus, although there is no long-term relationship for Morocco's trade opening, it turns out that trade interacts positively with the level of FDI.

On the other hand, the results show that foreign direct investment in ECOWAS has a positive and significant impact on GDP per capita in both the short and long term. This result can be explained by Morocco's integration into the global value chains and by the sectoral distribution of Moroccan FDI, which covers high value-added and booming segments. These were Banking (41.9\%), Telecommunications (24.2\%), Industry (12\%), Insurance 
$(8.6 \%)$ and Real Estate $(4.1 \%)$.

With regard to bilateral trade between Morocco and ECOWAS, no long-term equilibrium relationship could be established. The model represents a low quality of fit (37\%). Thus, despite the explosion of its exports since 2008 and the proximity of the African market, the national economy is slow to feel the spillover effects of these exchanges. Indeed, the low rate of complementarity and diversification of Morocco's export structure hinders these prospects for growth and transformation in both the short and long term. On the other hand, the volume of trade between the two entities remains very low and below its potential, while Morocco suffers from strong international competition from countries whose exports are much higher than those of Morocco.

\section{Conclusion}

The analysis of the trade relations between Morocco and ECOWAS reveals an increasing volume of trade, reflecting a continuous dynamization of their commercial relations. A similar trend is observed in foreign direct investment, which has been growing steadily over the last few years, reflecting Morocco's desire to become a major player in the development of the African continent.

However, ECOWAS still accounts for a small share of Morocco's trade. This weakness can be attributed to a number of factors, including insufficient diversification, sophistication and complexity of exported products and their unsuitability to meet demand, the low level of complementarity between Morocco's supply and demand for trade with ECOWAS countries, the lack of transport infrastructure, the weak dynamism of the partnership and the absence of appropriate frameworks for enhanced trade cooperation.

In terms of impact, no long-term equilibrium relationship between bilateral Moroccan-ECOWAS trade and economic growth in Morocco has been demonstrated due to the still low level of bilateral trade. On the other hand, Moroccan foreign direct investment in ECOWAS has a positive and significant impact on its GDP per capita, both in the short and long term. This result can be explained by the sectoral distribution of Moroccan FDI, which mainly concerns high value-added and booming segments.

Thus, Morocco is called upon to pursue, actively and over time, its strategic choice to strengthen its economic relations with ECOWAS countries and the rest of the African continent and to take new initiatives to promote reciprocal exchanges.

\section{References}

Alfaro, L., Chanda, A., Kalemli-Ozcan, S., \& Sayek, S. (2010). How Does Foreign Direct Investment Promote Economic Growth? Exploring the Effects of Financial Markets on Linkages.Journal of Development Economics, 91, 242-256. https://doi.org/10.1016/j.jdeveco.2009.09.004

Anand, S.,\& Sen, A. (2000). Human Development and Economic Sustainability.World Development, 28(12), 2029-2049. https://doi.org/10.1016/S0305-750X(00)00071-1

Apergis, N., Lyroudi, K., \& Vamvakidis, A. (2008). The relationship between foreign direct investment and economic growth: evidence from transition countries.Transition Studies Review, 15, 37-51. https://doi.org/10.1007/s11300-008-0177-0

Arnelyn, A., \& Felipe, A. (2011). The Product Space: What Does It Say About the Opportunities for Growth and Structural Transformation of Sub-Saharan Africa? Levy Economics Institute Working Paper $\mathrm{N}^{\circ}$ 670, May.

ECA-AU-AfDB. (2010). State of Regional Integration in Africa IV, Developing Intra-African Trade. Economic Commission for Africa, May 2010.

Engle, R. F., \& Granger, C.W. (1987). Cointegration and Error Correction: Representation, Estimation and Testing.Econometrica, 55, 251-276. https://doi.org/10.2307/1913236

Engle, R. F., \& Yoo, S. (1987). Forecasting and Testing in Cointegrated Systems.Journal of Econometrics, 35, 143-159. https://doi.org/10.1016/0304-4076(87)90085-6

Johansen S. (1991). Estimation and Hypothesis Testing of Cointegratinf Vectors in Gaussian Vector Autoregressive Models.Econometrica, 59. https://doi.org/10.2307/2938278

Johansen, S. (1988). Statistical Analysis of Cointegration Vectors.Journal of Economic Dynamics and Control, 12(2-3), 231-254. https://doi.org/10.1016/0165-1889(88)90041-3

Johansen, S.,\& Juselius, K. (1990). Maximum Likelihood Estimation and Inference on Cointegration with Applications to the Demand for Money.Oxford Bulletin of Economics and Statistics, 52(2), 169-210. https://doi.org/10.1111/j.1468-0084.1990.mp52002003.x 
Kojima, K. (1973). A macroeconomic approach to foreign direct investment.Hitotsubashi Journal of Economics, 14, 1-21.

Krugman, P. R., \&Obstfeld, M. (1995). International economics: theory and policy.

Li, Z. (2013). How Foreign Direct Investment Promotes Development. The Case of the People's Republic of China's Inward and Outward FDI. Asian Development Bank, p. 304.

Mankiw, N. G., Romer, D.,\& Weil, D. (1992). A Contribution to the Empirics of Economic Growth.The Quarterly Journal of Economics, 107(2), 407-37. https://doi.org/10.2307/2118477

Medvedev, D. (2012). Beyond trade: The impact of preferential trade agreements on FDI inflows.World Development, 40(1), 49-61. https://doi.org/10.1016/j.worlddev.2011.04.036

Ministry of Economy and Finance. (2015). Republic of Senegal: "Nature of interactions between foreign trade and FDI (complementarity or substitutability): What impacts of FDI on growth in Senegal".

Mustapha, M. (2011). Morocco relies on sub-Saharan Africa.Economic Trends, AFKAR/IDEES, Winter.

Pesaran, M.H., \& Shin, Y. (1998). An autoregressive distributed-lag modelling approach to cointegration analysis. In S. Strom (Ed.), Econometrics and Economic Theory in the 20th Century: The Ragnar Frisch Centennial Symposium(pp. 371-413). Cambridge: Cambridge University Press. https://doi.org/10.1017/CCOL0521633230.011

Pesaran, M.H., Smith, R.J., \& Shin, Y. (2001).Bounds testing approaches to the analysis of level relationships.Journal of Applied Economectrics, 16, 289-326. https://doi.org/10.1002/jae.616

Saeed, T. (2016).International trade and foreign direct investment: Complementarity or substitutability? Thesis Economics. Poitiers: University of Poitiers.

Yaméogo, N. et al. (2014). Diversification and Sophistication as Drivers of structural transformation for Africa: The economic complexity index of African countries. Paper first presented at the 40th Annual Conference of the Eastern Economic Association, 6-9 March; and also at the 17th Annual Conference on Global Economic Analysis on "New Challenges in Food Policy, Trade and Economic Vulnerability" in Dakar from 18-21 June.

\section{Notes}

Note 1. ECOWAS includes 15 countries (Benin, Burkina Faso, Ivory Coast, Gambia, Ghana, Ghana, Guinea, Guinea-Bissau, Liberia, Mali, Niger, Nigeria, Senegal, Sierra Leone, Togo and Cape Verde).

Note 2. The diversification index measures the absolute deviation of the structure of country $i$ from the structure of country $\mathrm{j}$ : The value of the diversification index is between 0 and 1 . The closer the index is to 1 , the greater the deviation from the structure of country $j$.

Note 3. The bilateral trade intensity indicator used for exports is as follows: $\mathrm{Iij}=(\mathrm{Xij} / \mathrm{Xi}) /(\mathrm{Mj} / \mathrm{Mw})$, with $\mathrm{Xij}$ the exports from country $i$ to country $j ; X i$ the total exports from country $i$; $\mathrm{Mj}$ the total imports from country $j$ and $\mathrm{Mw}$ the total world imports. If the index is above 1 , country $\mathrm{i}$ exports on average relatively more to country $\mathrm{j}$ than the world as a whole. In other words, country $i$ has a relatively strong preference for $j$ over export.

Note 4 . The complementarity index is a relevant trade indicator that indicates to what extent the export structure of a country $\mathrm{j}$ corresponds to the import structure of a country $\mathrm{k}$, partner country $\mathrm{j}$. The value of this index is between 0 and 100. It is equal to 0 when no product exported by one country is imported by the other. It is worth 100 when the structure of imports from one country corresponds exactly to that of exports from the other.

\section{Copyrights}

Copyright for this article is retained by the author(s), with first publication rights granted to the journal.

This is an open-access article distributed under the terms and conditions of the Creative Commons Attribution license (http://creativecommons.org/licenses/by/4.0/). 